\title{
FAKTOR RISIKO KERACUNAN PESTISIDA PADA PETANI HORTIKULTURA DI KABUPATEN LAMPUNG BARAT
}

\author{
Prayudhy Yushananta $^{1 *}$, Nia Melinda ${ }^{2}$, Arif Mahendra ${ }^{3}$, Mei Ahyanti ${ }^{4}$, Yetti Angraini ${ }^{5}$ \\ 1,2,3,4 Department of Environmental Health, Poltekkes Kemenkes Tanjungkarang. \\ 5 Department of Midwifery, Poltekkes Kemenkes Tanjungkarang
}

\section{Artikel Info :}

Received 27 Juli 2020

Accepted 15 Agustus 2020

Available online 24 Agustus

2020

Editor: Ferry Kriswandana

Key word :

Pesticides, cholinesterase, horticulture, PPE, dosage

\section{Kata Kunci :}

Pestisida, cholinesterase, hortikultura, APD, dosis

Ruwa Jurai: Jurnal

Kesehatan Lingkungan is licensed under a Creative Commons Attribution-NonCommercial 4.0 International License.

\begin{abstract}
Pesticide poisoning is still an important health problem in agricultural areas, especially horticultural agriculture. Various chronic health effects can be caused by long-term exposure to pesticides. This study aims to determine the risk factor of pesticide poisoning in horticultural farmers in West Lampung Regency. The study used a cross sectional design which was conducted in four different areas as the center of horticulture agriculture, West Lampung Regency, Lampung Province. The study involved 289 participants by interviewing, observing and examining blood samples to measure cholinesterase levels as an indicator of pesticide poisoning. In this section, we have applied research ethical procedures. The obtained data were analyzed using Chi square test, Odds Ratio test and Logistic Regression. The results showed that the risk factors for pesticide poisoning were incomplete use of personal protected equipment (PPE), spraying with the wrong dose and spraying frequency. Unwearing a complete PPE had a 4.54 times $(O R=4.54 ; 95 \% \mathrm{Cl} 2.09-9.83)$ higher risk of experiencing pesticide poisoning, and statistically suggested, a very significant relationship ( $p$-value $=0.0001)$. While the use of excessive dosage has a risk of 4.39 times $(O R=4.39 ; 95 \% \mathrm{Cl} 1.87-10.33$; $p$-value $=0.001)$; and the frequency of spraying more than twice a week had a 2.33 times higher risk of experiencing pesticide poisoning (OR $=2.33 ; 95 \% \mathrm{Cl} 1.24-4.40 ; p$-value $=0.009$ ). Excessive use of pesticide dosage and the frequency of spraying with the cover blanked method are the main factors of pesticide exposure to farmers. On the other hand, the use of PPE is a method of protection from exposure. It needs joint efforts through increasing knowledge about the dangers of pesticides, pesticide management, how to work safely, and the use of PPE.
\end{abstract}

Keracunan pestisida masih menjadi masalah kesehatan yang penting di daerah pertanian, khususnya pertanian hortikultura. Berbagai efek kesehatan kronik dapat ditimbulkan akibat paparan pestisida jangka panjang. Penelitian bertujuan untuk mengetahui faktor risiko keracunan pestisida pada petani hortikultura di Kabupaten Lampung Barat. Penelitian menggunakan rancangan cross sectional yang dilakukan di empat wilayah berbeda sebagai sentra pertanian hortikultura Kabupaten Lampung Barat, Provinsi Lampung. Penelitian melibatkan 289 orang partisipan dengan metode wawancara, observasi serta pemeriksaan sampel darah untuk pemeriksaan kadar cholinesterase sebagai indikator keracunan pestisida. Pada bagian ini, kami telah menerapkan prosedur etik penelitian. Data yang diperoleh, dianalisis menggunakan uji Chi squre, Odds Ratio dan Regresi Logistic. Hasil penelitian mendapatkan bahwa faktor risiko keracunan pestisida adalah penggunaan alat pelindung diri (APD) yang tidak lengkap, penyemprotan dengan dosis berlebihan dan frekuensi penyemprotan. Tidak menggunakan APD secara lengkap berisiko 4,54 kali $(O R=4,54 ; 95 \% \mathrm{Cl} 2,09-9,83)$ lebih tinggi mengalami keracunan pestisida, dan secara statistik menunjukkan hubungan yang sangat signifikan ( $p$-value $=0,0001$ ). Sedangkan penggunaan dosis berlebihan berisiko 4,39 kali (OR=4,39; 95\% Cl 1,87-10,33; $p$-value $=0,001$ ); dan frekuensi penyemprotan lebih dari 2 kali seminggu berisiko 2,33 kali lebih tinggi mengalami keracunan pestisida $(O R=2,33 ; 95 \% \mathrm{Cl}$ 1,24-4,40; $p$-value $=0,009)$. Penggunaan dosis pestisida secara berlebihan serta frekuensi penyemprotan dengan metode cover blanked, menjadi faktor utama paparan pestisida pada petani. Di sisi lain, penggunaan APD menjadi metode proteksi dari paparan. Perlu upaya bersama melalui peningkatan pengetahuan tentang bahaya pestisida, pengelolaan pestisida, cara bekerja dengan aman, dan penggunaan APD.

${ }^{*}$ Corresponding author: Prayudhy Yushananta

J. Soekarno-Hatta No 6, Bandar Lampung, Provinsi Lampung

Email : prayudhiyushananta@poltekkes-tjk.ac.id 


\section{PENDAHULUAN}

Penggunaan pestisida seringkali menimbulkan gangguan kesehatan baik terhadap petani maupun masyarakat sebagai konsumen hasil pertanian. Diperkirakan 1 sampai 5 juta kasus keracunan pestisida terjadi di dunia setiap tahunnya, dengan kematian mencapai 220.000 jiwa. Keracunan pestisida terjadi akibat penggunaan dengan dosis yang tidak tepat dan dilakukan secara terus menerus. Efek utama keracunan pestisida adalah gangguan sistem saraf seperti sakit kepala, pusing, paresthesia, tremor, diskoordinasi, kejang; serta menghambat enzim asetylcholinesterase yang mengganggu organ gerak. Dampak jangka panjang pestisida antara lain anemia, anoreksia, berkurangnya berat badan dan gangguan fungsi hati (Agustina \& Norfai, 2018; Arwin \& Suyud, 2016; Azmi, Naqvi, Azmi, \& Aslam, 2006; Britt \& Budinky A, 2000; Fauziyyah, Suhartono, \& Astorina, 2017; Kartini et al., 2019; Nassar, Salim, \& Malhat, 2016; Neghab, Jalilian, Taheri, Tatar, \& Haji Zadeh, 2018; Okvitasari, Anwar, \& Suparmin, 2016; Patil, Patil, \& Govindwar, 2003; Prasetyaningsih, Arisandi, \& Retnosetiawati, 2017; Sihana, Dawson, \& Buckley, 2019).

Salah satu pengguna pestisida terbesar pada pertanian adalah sektor pertanian hortikultura yang digunakan dalam dosis besar dan terus menerus selama musim tanam. Sehingga, petani tanaman holtikultural adalah populasi yang berisiko mengalami keracunan pestisida. Paparan pestisida terjadi pada saat persiapan peralatan, mencampur pestisida, penyemprotan, membersihkan alat dan pakaian kerja, membersihkan rumput dan hama, menyiram tanaman dan pemanenan.

Kabupaten Lampung Barat merupakan daerah pertanian hortikultura terluas di Provinsi Lampung. Berdasarkan sumber pendapatan daerah, sektor pertanian (dalam hal ini tanaman pangan dan hortikultura) merupakan sektor yang sangat vital dan strategis bagi perekonomian dengan rerata kontribusi pendapatan sebesar $53,81 \%$ PDRB. Luas lahan pertanian hortikultura seluas $1.254 \mathrm{Ha}$ dengan produksi tanaman sayuran sebesar 237.500 ton yang terdiri dari bawang merah, kentang, cabai dan kubis (BPS, 2019).

Namun, hingga saat ini belum terdapat pemetaan dampak penggunaan pestisida terhadap kesehatan petani. Pengukuran paparan bahan kimia termasuk pestisida dan pemeriksaan kesehatan akibat paparan bahan kimia, seharusnya dilakukan secara rutin sebagai upaya menjamin dan melindungi keselamatan dan kesehatan pekerja (Depnaker, 1986; Kemenaker RI, 2018). Penelitian bertujuan untuk mengetahui faktor risiko keracunan pestisida pada petani hortikultura di Kabupaten Lampung Barat. Penelitian ini telah melalui kaji etik oleh Komisi Etik Penelitian Kesehatan Politeknik Kesehatan Tanjungkarang, dengan Ethical cleareance nomor 211/EA/KEPK-TJK/VII/2019.

\section{METODE}

\section{Subjek Penelitian}

Penelitian bertujuan mengetahui faktor risiko keracunan pestisida pada petani hortikultura dengan menggunakan rancangan cross sectional. Jumlah sampel sebanyak 289 orang yang tersebar di 4 kecamatan sentra pertanian hortikultura, yaitu Kecamatan Balik Bukit, Sukau, Sikincau, dan Way Tenong (Gambar 1). Pemilihan sampel dilakukan dengan metode random, dan besar sampel pada masing-masing lokasi mengikuti jumlah petani hortikultura secara proporsional. Pengambilan data dilakukan dengan wawancara dan melakukan observasi pada setiap responden. Pada akhir wawancara, dilakukan pengambilan sampel darah untuk mengukur kadar Cholinestrase untuk mengetahui efek keracunan dari penggunaan pestisida.

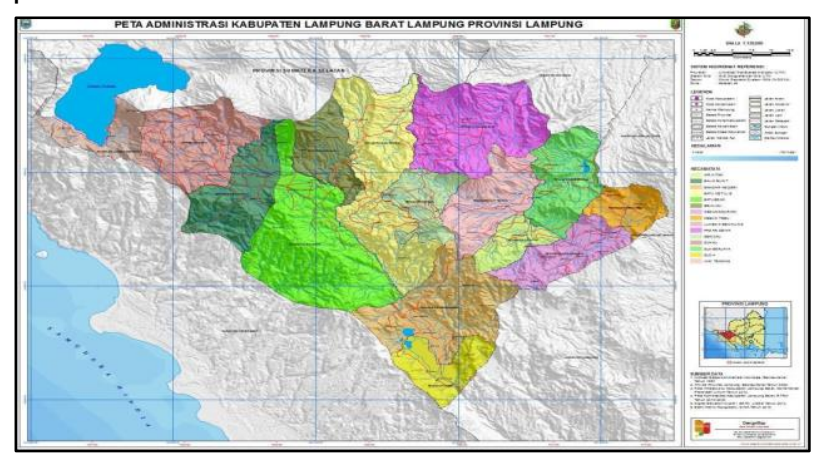

Gambar 1. Peta Kabupaten Lampung Barat (BPS, 2019)

\section{Sampel darah}

Sampel darah diambil dari pembuluh darah vena menggunakan jarum suntik heparinized untuk menghindari pembekuan. Pembuatan 
serum darah dilakukan in-situ dengan pemutaran pada 500 RPM selama 15 menit. Serum dikirim pada suhu $4^{\circ} \mathrm{C}$ untuk dilakukan pemeriksaan di Laboratorium Politeknik Kesehatan Tanjungkarang. Pengukuran kadar cholinesterase menggunakan spektrofotometer pada panjang gelombang $405 \mathrm{~nm}$.

\section{Analisis Data}

Pada penelitian ini, kami menggunakan perangkat lunak statistik SPSS 20.0 untuk menganalisis data, dan dilakukan secara bertahap. Analisis univariat menggunakan frekuensi dan proporsi; bivariat menggunakan chi square dan Odds Ratio; dan multivariat dengan Regresi Logistic.

\section{HASIL}

Hasil penelitian pada Tabel 1 menunjukkan bahwa sebanyak $24,6 \%$ petani mengalami keracunan pestisida, ditandai dengan kadar enzim cholinesterase $<3990 \mu / L$, dan lebih dari separuh petani bekerja lebih dari 5 jam per hari (68,2\%\%).

Pada Tabel 2 terlihat bahwa sebagian besar responden $(79,2 \%)$ telah bekerja pada pertanian holtikultura lebih dari 5 tahun. Namun, sebanyak $63,3 \%$ masih bekerja dengan cara yang berisiko keracunan.

Penelitian ini juga menunjukkan bahwa penyemprotan tanaman dilakukan lebih dari 2 kali seminggu (59,5\%), dan sebanyak 67,8\% menggunakan pestisida dengan dosis yang berlebihan. Sebanyak 62,3\% petani tidak menggunakan alat pelindung diri (APD) secara lengkap untuk melindungi dirinya dari paparan pestisida, dan sebanyak $40,5 \%$ petani masih memiliki pengetahuan yang kurang baik dalam pengelolaan pestisida.

Tabel 1: Distribusi Keracunan Responden

\begin{tabular}{lll}
\hline Variabel & $\mathrm{n}$ & $\%$ \\
\hline Keracunan & 71 & 24,6 \\
Tidak Keracunan & 218 & 75,4 \\
\hline
\end{tabular}

Dilakukan analisis chi square untuk mengetahui hubungan masing-masing variabel independen dengan keracunan pestisida. Hasil analisis tidak menunjukkan hubungan yang signifikan pada variabel lama bekerja ( $p$-value $=$
$0,792)$, masa kerja ( $p$-value $=0,077)$, cara kerja $(p$-value $=0,471)$, dan pengetahuan $(p$-value $=$ 0,946). Sedangkan variabel yang menunjukkan hubungan yang signifikan dengan keracunan pestisida adalah frekuensi penyemprotan ( $p$ value $=0,004)$, dosis pestisida $(p$-value $=0,000)$, dan penggunaan APD ( $p$-value $=0,000$ ).

Dilakukan analisis multivariat untuk mengetahui hubungan yang valid serta variabel yang dominan antara variabel independen dengan keracunan pestisida. Hasil analisis mendapatkan bahwa variabel yang paling tinggi risikonya terhadap keracunan pestisida adalah penggunaan APD yang tidak lengkap (Tabel 3). Tidak menggunakan APD secara lengkap berisiko 4,45 kali (OR=4,54; $95 \% \mathrm{Cl}=2,09-9,83)$ lebih tinggi mengalami keracunan pestisida, dibandingkan yang menggunakan APD secara lengkap. Secara statistik, kedua variabel menunjukkan hubungan yang sangat signifikans ( $p$-value $=0,0001)$.

Pada Table 3 juga terlihat bahwa penggunaan dosis pestisida berlebihan mempunyai risiko 4,39 kali $(O R=4,39 ; 95 \% C l=1,87-10,33)$ lebih tinggi untuk mengalami keracunan pestisida, dan secara statistik menunjukkan hubungan yang signifikans ( $p$-value $=0,001)$. Sedangkan frekuensi penyemprotan lebih dari 2 kali seminggu, berisiko 2,33 kali $(\mathrm{OR}=2,33$; $95 \% \mathrm{Cl}=1,24-4,40)$ lebih tinggi mengalami keracunan pestisida, dengan kemaknaan statistik sebesar 0,009.

\section{PEMBAHASAN}

Keracunan pestisida dalam darah diukur dengan metode kinetic yang ditandai adanya reaksi potasium ferosianida menjadi potasium ferisianida akibat reaksi reduksi. Spektrofotometer digunakan untuk pembacaan hasil pada panjang gelombang $405 \mathrm{~nm}$. Hasilnya menunjukkan sebanyak $24,6 \%$ petani hortikulutura mengalami keracunan. Masuknya racun pestisida melalui kulit, mulut, dan saluran pernapasan, akan mengganggu kerja enzim Cholinesterase dalam darah, yang berperan dalam menghantarkan impuls sepanjang serabut saraf (Agustina \& Norfai, 2018; Azmi et al., 2006; Del Prado-Lu, 2007; Eskenazi et al., 2004; Istianah. \& Yuniastuti, 2017; Kapeleka, Sauli, Sadik, \& Ndakidemi, 2019; Rustia, Wispriyono, Susana, \& Luthfiah, 2010; Yushananta, Ahyanti, \& Anggraini, 2020). Efek keracunan akibat 
paparan pestisida berlebihan adalah gejala sistem saraf seperti sakit kepala, pusing, paresthesia, tremor, diskoordinasi,

kejang. Sedangkan efek kronis jangka panjang dapat mengakibatkan berat badan menurun, anemia, anorexia, dan neuropati tertunda (Agustina \& Norfai, 2018; Azmi et al., 2006; Britt \& Budinky A, 2000; Prasetyaningsih et al., 2017; Sihana et al., 2019; Yushananta et al., 2020).

Tabel 2: Distibusi dan Hubungan Variabel Penelitian dengan Keracunan Pestisida

\begin{tabular}{|c|c|c|c|c|c|c|c|c|c|}
\hline Variabel & & $\mathrm{n}$ & $\%$ & $\mathrm{n}$ & $\%$ & $\mathrm{n}$ & $\%$ & $\begin{array}{l}\mathrm{p}- \\
\text { Value }\end{array}$ & OR $95 \% \mathrm{Cl}$ \\
\hline \multirow[t]{2}{*}{ Lama Bekerja } & $>5$ jam sehari & 197 & 68,2 & 47 & 23,86 & 150 & 76,14 & \multirow[b]{2}{*}{0,792} & 0,89 \\
\hline & $<5$ jam sehari & 92 & 31,8 & 24 & 26,09 & 68 & 73,91 & & $\begin{array}{l}0,5092- \\
1,57\end{array}$ \\
\hline \multirow[t]{2}{*}{ Masa kerja } & $>5$ tahun & 229 & 79,2 & 62 & 27,07 & 167 & 72,93 & \multirow{2}{*}{0,077} & \\
\hline & 1-5 tahun & 60 & 20,8 & 9 & 15 & 51 & 85 & & $0,98-4,53$ \\
\hline \multirow[t]{2}{*}{ Cara Kerja } & $<$ Kurang Baik & 183 & 63,3 & 48 & 26,23 & 135 & 73,77 & \multirow{2}{*}{0,471} & 1,28 \\
\hline & Baik & 106 & 36,7 & 23 & 21,7 & 83 & 78,3 & & $0,73-2,26$ \\
\hline \multirow[t]{2}{*}{$\begin{array}{l}\text { Frekuensi } \\
\text { Penyemprotan }\end{array}$} & $\begin{array}{l}>2 \text { kali } \\
\text { semingqu }\end{array}$ & 172 & 59,5 & 53 & 30,81 & 119 & 69,19 & \multirow{2}{*}{0,004} & 2,45 \\
\hline & $\begin{array}{l}1-2 \text { kali } \\
\text { seminggu }\end{array}$ & 117 & 40,5 & 18 & 15,38 & 99 & 84,62 & & $1,35-4,45$ \\
\hline \multirow[t]{2}{*}{ Dosis Pestisida } & Melebihi Dosis & 196 & 67,8 & 64 & 32,65 & 132 & 67,35 & \multirow{2}{*}{0,000} & 5,957 \\
\hline & Sesuai Dosis & 93 & 32,2 & 7 & 7,53 & 86 & 92,47 & & $2,61-13,61$ \\
\hline \multirow[t]{2}{*}{ Penggunaan APD } & Tidak Lengkap & 180 & 62,3 & 62 & 34,44 & 118 & 65,56 & \multirow{2}{*}{0,000} & 5,84 \\
\hline & Lengkap & 109 & 37,7 & 9 & 8,26 & 100 & 91,74 & & $2,76-12,34$ \\
\hline \multirow[t]{2}{*}{ Pengetahuan } & Kurang Baik & 117 & 40,5 & 28 & 23,93 & 89 & 76,07 & \multirow{2}{*}{0,946} & 0,94 \\
\hline & Baik & 172 & 59,5 & 43 & 25 & 129 & 75 & & $0,55-1,63$ \\
\hline
\end{tabular}

Hasil penelitian mendapatkan tiga variabel yang berhubungan dengan keracunan pestisida, yaitu penggunaan APD yang tidak lengkap, dosis pestisida berlebihan, dan frekuensi penyemprotan lebih dari 2 kali seminggu. APD adalah perlengkapan kerja yang harus digunakan saat melakukan penyemprotan pestisida agar terlindungi dari paparan pestisida, terdiri dari topi, kacamata, masker, baju lengan panjang, sarung tangan, celana panjang, dan sepatu bot (Depnaker, 1986). Hasil penelitian mendapatkan bahwa penggunaan APD yang tidak lengkap merupakan variabel yang paling dominan berhubungan dengan kejadian keracunan pestisida, dengan nilai risiko sebesar 4,54 kali. Penggunaan APD merupakan variabel yang berhubungan signifikan dengan keracunan pada petani (Istianah. \& Yuniastuti, 2017). Penelitian lain juga menyampaikan hasil yang sama (Arwin \& Suyud, 2016; Azmi et al., 2006; Del Prado-Lu, 2007; Kapeleka, Sauli, Sadik, \& Ndakidemi, 2019; Kurniasih, Setiani, \& Nugraheni, 2013; Okvitasari et al., 2016; Prasetyaningsih et al., 2017). Perilaku tidak menggunakan APD secara lengkap pada saat mengaplikasikan pestisida merupakan kebiasaan yang dilakukan secara terus menerus, termasuk dalam mencampur pestisida (Arwin \& Suyud, 2016; Istianah. \& Yuniastuti, 2017). Penggunaan APD yang rendah menunjukkan kurangnya pemahaman petani tentang risiko pestisida (Fauziyyah et al., 2017) 
Tabel 3: Hasil analisis Multivariat

\begin{tabular}{llllll}
\hline Keracunan & $\mathrm{B}$ & $\mathrm{SE}$ & $\mathrm{p}$-wald & OR & $95 \% \mathrm{Cl}$ \\
\hline Penggunaan APD & 1,512 & 0,394 & 0,0001 & 4,54 & $2,09-9,83$ \\
Frekuensi Penyemprotan & 0,847 & 0,324 & 0,009 & 2,33 & $1,24-4,40$ \\
Dosis Pestisida & 1,481 & 0,436 & 0,001 & 4,39 & $1,87-10,33$ \\
Constanta & $-3,936$ & 0,552 & 0,0001 & 0,02 & \\
\hline
\end{tabular}

Masuknya pestisida ke dalam tubuh melalui beberapa cara (portal of enty), yaitu kulit, pernafasan, dan pencernaan. Cara yang paling sering adalah melalui kulit, dan penyerapannya akan semakin efektif apabila terdapat kelainan kulit atau keringat. Sedangkan keracunan melalui pernafasan merupakan kasus terbanyak kedua setelah kontaminasi kulit (Kurniasih et al., 2013). Penggunaan APD berperan untuk menutup pintu masuk (portal of enty), sehingga tubuh terlindungi dari paparan pestisida. APD merupakan upaya penggunaan alat yang berfungsi untuk mengisolasi sebagian atau seluruh tubuh dari sumber bahaya (Kemenaker $\mathrm{RI}$, 2018). Keracunan pestisida disebabkan tidak terlindungnya tubuh saat kontak dengan pestisida (Kurniasih et al., 2013; Prasetyaningsih et al., 2017).

Dosis pestisida adalah jumlah pestisida yang digunakan pada saat penyemprotan tanaman hortikultura. Hasil penelitian mendapatkan sebanyak $67,8 \%$ petani menggunakan dosis yang berlebihan, tidak sesuai takaran seperti tercantum pada label kemasan. Penggunaan dosis hanya berdasarkan kebiasaan atau pengalaman petani lain. Besarnya risiko mengalami keracunan akibat penggunaan dosis yang berlebihan sebesar 4,39 kali. Selain menyebabkan keracunan, penggunaan pestisida dengan dosis besar dan secara terus-menerus dapat menimbulkan beberapa kerugian, antara lain terakumulasinya residu pestisida pada produk pertanian, pencemaran lingkungan pertanian, penurunan produktivitas, dan keracunan pada hewan non target (Agustina \& Norfai, 2018; Fauziyyah et al., 2017; Istianah. \& Yuniastuti, 2017; Kurniasih et al., 2013; Okvitasari et al., 2016; Rustia et al., 2010).

Metode penyemprotan pestisida yang tidak didasarkan pada pengendalian indikatif, juga menjadi variabel yang berhubungan dengan keracunan pestisida. Pengendalian non-indikatif adalah penyemprotan yang dilakukan tanpa melihat ada atau tidaknya hama pada tanaman atau dilakukan secara "Cover Blanket System" (Prasetyaningsih et al., 2017; Yushananta et al., 2020) Pada penelitian ini, risiko mengalami keracunan pada petani yang melakukan penyemprotan lebih dari 2 kali seminggu sebesar 2,33 kali. Frekuensi penyemprotan berkaitan dengan frekuensi paparan pestisida.

Menghindari keracunan sekaligus meningkatkan efektifitas penggunaan pestisida sebaiknya penyemprotan dilakukan pada sore hari (pukul 16.00-17.00), ketika suhu udara kurang dari $30^{\circ} \mathrm{C}$, kelembaban $50-80 \%$, dan kecepatan angin 3-5 km/jam. Penyemprotan pada pagi hari, kandungan uap air masih tinggi sehingga bercampur dengan butiran semprot yang berakibat menurunnya efektifitas atau daya bunuh pestisida. Sedangkan penyemprotan yang dilakukan pada siang hari saat matahari terik, suhu udara di atas permukaan tanah lebih rendah, sehingga akan terjadi pergerakan udara dari bawah ke atas (turbulensi) yang akan menerbangkan butiran semprot. Penguapan akan menurunkan efektifitas penyemprotan dan meningkatkan paparan yang masuk lewat kulit (Kementan, 2020; Novizan, 2008).

Tiga variabel hasil analisis multivariat membuktikan bahwa keracunan pestisida berkaitan erat dengan jumlah atau dosis paparan dan frekuensi paparan. Semakin sering terpapar dengan dosis yang tinggi, akan meningkatkan risiko keracunan pestisida (Britt \& Budinky A, 2000). Di sisi lain, penelitian juga menunjukkan bahwa penggunaan APD menjadi pemutus kontak atau penghalang dari paparan pestisida. Pola hubungan ketiga variabel dapat dijelaskan pada Gambar 2. 


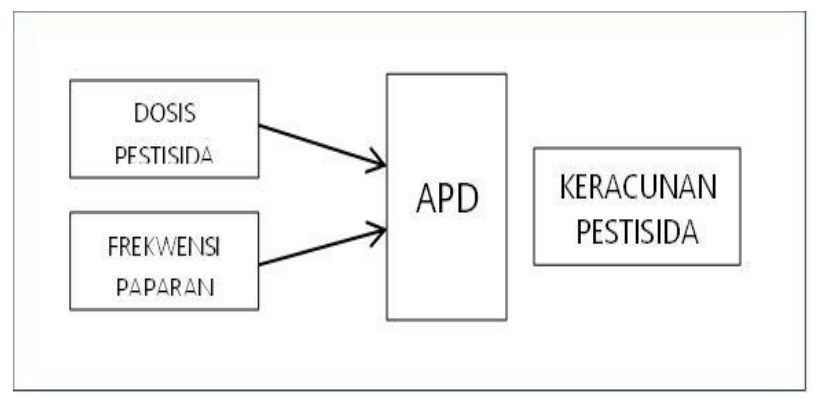

Gambar 2. Hubungan dosis, frekuensi paparan, APD dan keracunan pestisida

Gambar 2 menunjukkan bahwa APD berperan sebagai proteksi dari paparan pestisida. Namun demikian, penggunaan pestisida dengan dosis berlebih serta frekuensi penyemprotan berlebihan tidak disarankan, karena residu pestisida akan berdampak pada produk pertanian, pencemaran lingkungan pertanian, penurunan produktivitas, dan keracunan pada hewan non target (Agustina \& Norfai, 2018; Fauziyyah et al., 2017; Istianah. \& Yuniastuti, 2017; Kurniasih et al., 2013; Okvitasari et al., 2016; Rustia et al., 2010).

Walaupun pada penelitian ini tidak menunjukkan hubungan statistik yang bermakna, keracunan pestisida diduga juga berkaitan dengan lama bekerja, masa kerja, cara kerja, dan pengetahuan. Hasil penelitian mendapatkan bahwa sebagian besar petani telah bekerja pada pertanian hortikultura lebih dari 5 tahun (79,2\%), bekerja lebih dari 5 jam setiap harinya $(68,2 \%)$, dan bekerja dengan cara yang berisiko mengalami keracunan (63,3\%). Lamanya waktu kerja berkaitan dengan lama paparan harian, sedangkan masa kerja berkaitan dengan risiko gangguan kesehatan kronis. Semakin lama waktu kerja dan masa kerja, maka semakin besar pula risiko keracunan pestisida (Agustina \& Norfai, 2018; Arwin \& Suyud, 2016; Istianah. \& Yuniastuti, 2017; Kapeleka et al., 2019; Kurniasih et al., 2013; Okvitasari et al., 2016; Rustia et al., 2010). Menurut Permenaker No.Per-03/Men/1986 pasal 2 ayat 21, tenaga kerja yang mengelola pestisida tidak boleh mengalami pemaparan $>5$ jam sehari dan 20 jam dalam seminggu (Depnaker, 1986).

Menyemprot tanpa memperhatikan arah angin, bekerja di dekat lahan yang sedang di semprot, bekerja tanpa menggunakan APD secara lengkap, makan dan minum sambil bekerja, dan membuang kemasan di sembarang tempat, merupakan cara kerja yang umum ditemukan pada petani hortikultura. Cara kerja yang kurang baik akan meningkatkan risiko keracunan pestisida (Del Prado-Lu, 2007; Istianah. \& Yuniastuti, 2017; Kapeleka et al., 2019; Kurniasih et al., 2013)

Pengetahuan seseorang terhadap suatu objek akan berpengaruhi pada sikap yang ditunjukkan, yang selanjutnya mempengaruhi perilaku. Pada penelitian ini, hampir separuh petani memiliki pengetahuan yang kurang baik tentang pengelolaan pestisida. Walaupun secara statistik tidak berhubungan, namun tingkat pengetahuan diduga ikut berperan dalam perilaku penggunaan APD dan cara kerja. Pengetahuan tentang penggunaan pestisida secara aman akan bermanfaat bagi petani, masyarakat dan lingkungan (Istianah. \& Yuniastuti, 2017).

Strategi intervensi utama yang harus dilakukan untuk menurunkan risiko keracunan pestisida pada petani hortikultura adalah minimasi paparan, melalui penggunaan dosis yang adekuat, frekuensi penyemprotan dengan pendekatan pengendalian indikatif, serta penggunaan APD secara lengkap. Meningkatkan pengetahuan dan keterampilan tentang bahaya pestisida, cara pengelolaan dan mengaplikasikan pestisida yang tidak berisiko, menjadi tuntutan intervensi mendesak yang harus dilakukan untuk mengurangi risiko keracunan pestisida. Di sisi lain, pengukuran paparan pestisida di lokasi pertanian serta pemeriksaan kesehatan akibat paparan pestisida pada petani juga harus dilakukan secara periodik oleh pengawas dan pemeriksa ketenagakerjaan, untuk menjamin dan melindungi keselamatan dan kesehatan pekerja (Depnaker, 1986; Kemenaker RI, 2018).

\section{SIMPULAN}

Penelitian ini memberikan informasi yang berguna mengenai paparan pestisida pada pertanian hortikultura. Penggunaan APD yang tidak lengkap, paparan pestisida dengan dosis yang berlebihan serta tingginya frekuensi penyemprotan, menjadi faktor risiko terjadinya keracunan pestisida.

Meningkatkan pengetahuan tentang bahaya pestisida dan keterampilan cara 
pengelolaan dan mengaplikasikan pestisida, menjadi tuntutan mendesak yang harus dilakukan untuk mengurangi risiko keracunan pestisida. Di sisi lain, pengawasan dan pengukuran paparan pestisida serta dampak kesehatan akibat paparan pada petani, juga harus dilakukan secara periodik untuk menjamin dan melindungi keselamatan dan kesehatan pekerja.

\section{DAFTAR PUSTAKA}

Agustina, N., \& Norfai, N. (2018). Paparan Pestisida terhadap Kejadian Anemia pada Petani Hortikultura. Majalah Kedokteran Bandung, 50(4), 215-221. https://doi.org/10.15395/mkb.v50n4.1398

Arwin, N. M., \& Suyud, S. (2016). Pajanan pestisida dan kejadian anemia pada petani holtikultura di Kecamatan Cikajang , Kabupaten Garut tahun 2016. Berita Kedokteran Masyarakat, 32(7), 245250.

Azmi, M. A., Naqvi, S. N. H., Azmi, M. A., \& Aslam, M. (2006). Effect of pesticide residues on health and different enzyme levels in the blood of farm workers from Gadap (rural area) KarachiPakistan. Chemosphere, 64(10), 1739-1744. https://doi.org/10.1016/j.chemosphere.2006.01. 016

BPS. (2019). Provinsi Lampung Dalam Angka 2019. Bandar lampung: BPS Provinsi Lampung.

Britt, J. K., \& Budinky A, R. (2000). Principles of toxicology: Environmental and Industrial Applications, 2nd edition. In L. P. Williams, C. R. James, \& M. S. Roberts (Eds.), John Wiley \& Sons, Inc (2nd ed.). https://doi.org/10.1136/oem.58.8.545a

Del Prado-Lu, J. L. (2007). Pesticide exposure, risk factors and health problems among cutflower farmers: A cross sectional study. Journal of Occupational Medicine and Toxicology, 2(1), 1-8. https://doi.org/10.1186/1745-6673-2-9

Depnaker. Permenaker No 3 Tahun 1986 Tentang Syarat-Syarat Keselamatan dan Kesehatandi Tempat Kerja Yang Mengelola Pestisida. , Pub. L. No. No 3 Tahun 1986, 1 (1986).

Eskenazi, B., Harley, K., Bradman, A., Weltzien, E., Jewell, N. P., Barr, D. B., ... Holland, N. T. (2004). Association of in utero organophosphate pesticide exposure and fetal growth and length of gestation in an agricultural population. Environmental Health Perspectives, 112(10), 1116-1124. https://doi.org/10.1289/ehp.6789

Fauziyyah, R., Suhartono, \& Astorina, N. (2017).
Studi Praktik Penggunaan Pestisida Dan Kejadian Anemia Pada Petani Buah Di Desa Tunggak Kecamatan Toroh Kabupaten Grobogan. Jurnal Kesehatan Masyarakat (eJournal), 5(5), 860-870.

Istianah., \& Yuniastuti, A. (2017). Hubungan Masa Kerja, Lama Menyemprot, Jenis Pestisida, Penggunaan APD dan Pengelolaan Pestisida dengan Kejadian Keracunan Pada Petani di Brebes. Public Health Perspective Journal, 2(2), 117-123.

Kapeleka, J. A., Sauli, E., Sadik, O., \& Ndakidemi, P. A. (2019). Biomonitoring of Acetylcholinesterase (AChE) Activity among Smallholder Horticultural Farmers Occupationally Exposed to Mixtures of Pesticides in Tanzania. Journal of Environmental and Public Health, 2019, 1-11.

https://doi.org/10.1155/2019/3084501

Kartini, A., Subagio, H. W., Hadisaputro, S., Kartasurya, M. I., Suhartono, S., \& Budiyono, B. (2019). Pesticide exposure and stunting among children in agricultural areas. International Journal of Occupational and Environmental Medicine, 10(1), 17-29.

https://doi.org/10.15171/IJOEM.2019.1428

Kemenaker RI. Peraturan Menteri Ketenaga Kerjaan Republik Indonesia No. 5 tahun 2018 tentang Keselamatan dan Kesehatan Kerja Lingkungan Kerja. , 4 Kemenaker RI § (2018).

Kementan, B. (2020). Teknik Penyemprotan

Pestisida. Balitbang Pertanian, Kemnetan RI.

Retrieved from

hortikultura.litbang.pertanian.go.id

Kurniasih, S. A., Setiani, O., \& Nugraheni, S. A. (2013). Faktor-faktor yang Terkait Paparan Pestisida dan Hubungannya dengan Kejadian Anemia pada Petani Hortikultura di Desa Gombong Kecamatan Belik Kabupaten Pemalang Jawa Tengah. Jurnal Kesehatan Lingkungan Indonesia, 12(2), 132-137. https://doi.org/10.14710/jkli.12.2.132

Nassar, A. M. K., Salim, Y. M., \& Malhat, F. M. (2016). Assessment of pesticide residues in human blood and effects of occupational exposure on hematological and hormonal qualities. Pakistan Journal of Biological Sciences, 19(3), 95-105.

https://doi.org/10.3923/pjbs.2016.95.105

Neghab, M., Jalilian, H., Taheri, S., Tatar, M., \& Haji Zadeh, Z. (2018). Evaluation of hematological and biochemical parameters of pesticide retailers following occupational exposure to a mixture of pesticides. Life Sciences, 202(April), 182-187. 
https://doi.org/10.1016/j.lfs.2018.04.020

Novizan. (2008). Petunjuk Pemakaian Pestisida (1st ed.). Jakarta: AgroMedia Pustaka.

Okvitasari, R., Anwar, C., \& Suparmin. (2016). Hubungan Antara Keracunan Pestisida Dengan Kejadian Anemia Pada Petani Kentang Di Gabungan Kelompok Tani Al Farruq Desa Patak Banteng Kecamatan Kejajar Kabupaten Wonosobo Tahun 2016. Politeknik Kesehatan Kemenkes Semarang, 299-310.

Patil, J. A., Patil, A. J., \& Govindwar, S. P. (2003). Biochemical effects of various pesticides on sprayers of grape gardens. Indian Journal of Clinical Biochemistry, 18(2), 16-22. https://doi.org/10.1007/BF02867362

Prasetyaningsih, Y., Arisandi, D., \& Retnosetiawati, P. D. (2017). Persentase Kejadian Anemia Pada Petani Terpapar Pestisida Di Kelompok Tani
Karang Rejo, Dusun Krinjing Lor, Desa Jatisarono, Kecamatan Naggulan, Kabupaten Kulon Progo. THE 5TH URECOL PROCEEDING, (February), 452-457. Retrieved from http://lpp.uad.ac.id/wpcontent/uploads/2017/05/59.-yuliana-prasetya452-457.pdf

Rustia, H. N., Wispriyono, B., Susana, D., \& Luthfiah, F. N. (2010). Lama Pajanan Organofosfat Terhadap Penurunan Petani Sayuran. Makara Kesehatan, 14(2), 95-101.

Sihana, F., Dawson, A. H., \& Buckley, N. A. (2019). A bedside test for methemoglobinemia, Srilanka. Bulletin of the World Health Organization A, 1-5. Yushananta, P., Ahyanti, M., \& Anggraini, Y. (2020). Risk of pesticides on anaemia events in horticulture farmers. International Journal of Innovation, Creativity and Change, 13(2), 30-40. 